\title{
Preterm Infants' Weight Gain and Nutrition: Retrospective Study in a Top Indonesian Referral Hospital
}

\author{
Dewi Irianti ${ }^{1}$, Yeni Rustina ${ }^{2}$, Defi Efendi ${ }^{3 *}$ \\ ${ }^{1}$ Institute of Health Science Intan Martapura, Indonesia \\ ${ }^{2}$ Faculty of Nursing, Universitas Indonesia \\ ${ }^{3}$ Faculty of Nursing, Universitas Indonesia; Clinical Nurse Specialist, Neonatal Intensive Care Unit, \\ Universitas Indonesia Hospital \\ Corresponding author: defiefendi@ui.ac.id
}

\begin{abstract}
Background: Impairment of nutritional fulfillment is one of the problems that is often encountered in premature infants.

Purpose: This study aimed to determine the effect of the type of nutrition on the weight increase of premature babies.

Methods: A retrospective study was conducted through a medical record review in a top national referral hospital, Indonesia. Total of 75 preterm infants divided into groups of 15 infants by nutrition type (100\% BM, 75\% BM, 50\% BM, 25\% BM, and 0\% BM). Weight gain was assessed for 12 days through the patients' medical records. Weighing observation was devided into four times: birth weight in day-1, day-4, day-8, and day-12. Subjects were recruited using consecutive sampling with the following criteria: preterm infants with chronological age $>7$ days and weight $>1000$ grams. Meanwhile, the exclusion criteria were preterm infants treated in the neonatal intensive care unit (NICU), preterm infants with medical diagnosis of hydrocephalus, sepsis, and congenital anomalies, conjoined twin babies. The general linear model-repeated measure was used to quantify the contrast of increases in infants' body weight among groups for days 1-4; 4-8; and 8-12.

Results: There were no significant differences between the five types of nutrients in terms of increase in the infants' body weight in day 1-4 ( $p>0,68)$; day 4-8 $(\mathrm{p}>0,65)$; day 8-12 ( $\mathrm{p}$ $>0,12$ ).

Conclusion: Although it not likely to accelerate the infant's weight, mother's own milk is still the first recommendation due to its immunity components, nutritional elements, and safety.
\end{abstract}

Keywords: Weight Gain, Preterm Infants, Breast Milk, Type Of Nutrition. 
Journal Of Nursing Practice

http://thejnp.org

ISSN: 2614-3488 (print); 2614-3496 (online)

Vol.4 No.2. April 2021. Page.212-218

\section{BACKGROUND}

About $36 \%$ of preterm infants were reported as having digestive problems. Such condition was caused by sepsis, respiratory distress syndrome, phototherapy, and mothers who suffer from diabetes mellitus (Ahammad, Begum, and Nasrin, 2018). Health problems related to digestion in preterm infants could affect their weight gain (Namiiro, Mugalu, McAdams, Ndeezi, 2012).

Breast milk is the essential nutrition for preterm infants and has numerous benefits, such as protecting against infection; improving cognitive skills; reducing short-term and long-term morbidity risk; shortening the hospitalization period; increasing the mother-baby bond; preventing necrotizing enterocolitis (NEC), gastrointestinal infection, respiratory tract infection, otitis media, obesity, and sudden infant death syndrome; lowering the risk of breast and ovarian cancer, osteoporosis, type II diabetes, cardiovascular diseases, and rheumatoid arthritis (Meier, Engstom, Patel, Jegier \& Bruns, 2010). However, some clinicians propose infant formula as the main substitution to reach expected weight gain regardless of its other impacts on preterm infants.

A study conducted by Wojkowska-Mach, Rozanska, Borszewska-Kornacka et al. (2014) stated that formula feeding for preterm infants could increase the risk of NEC and sepsis. NEC can cause ischemia or toxicosis, which might damage the gastrointestinal mucosa, cause loss of mucosa integrity, and trigger bacteria proliferation in the mucosa. Such condition could allow bacteria to easily invade the digestive tract. This process could lead to intestinal necrosis and cause sepsis. NEC is one of the causes of preterm infant death. This study aims to compare breastfeeding and formula feeding in preterm infant weight gain. We hypothesized that preterm newborn weight gain is associated with the kind of nutritional intake.

\section{OBJECTIVE}

This study aimed to determine the effect of the type of nutrition on the weight increase of premature babies

\section{METHODS}

Design and samples

A retrospective study was conducted through a medical record review.

The subjects were to be divided into five groups. Using Winpepi 11.65 with the power of 0.80 for an $\alpha$ value of 0.05 , the standard deviation of the groups was respectively 71 and 60 , with a minimal significant difference of 70 . Therefore, a minimum of 70 total subjects was needed. Seventy-five subjects were recruited using consecutive sampling with the following criteria: preterm infants with chronological age $>7$ days and weight $>1000$ grams. Meanwhile, the exclusion criteria were preterm infants treated in the neonatal intensive care unit (NICU), preterm infants with medical diagnosis of hydrocephalus, sepsis, and congenital anomalies, conjoined twin babies, and preterm infants who were breastfed with human milk fortifier (HMF) and formula fed with nutrient dense formula containing $30 \mathrm{kkal} / \mathrm{oz}$. The investigation was conducted in a top national referral hospital in Jakarta, Indonesia.

Research instrument and data collection

The samples were 75 preterm infants and consisted of 15 infants who were $100 \%$ breastfed, 15 infants who were $75 \%$ breastfed, 15 infants who were $50 \%$ breastfed, 15 infants who were $25 \%$ breastfed, and 15 infants who were $0 \%$ breastfed. Infant weight was assessed within 12 days based on the infants' medical records. The observation was divided into four 


\section{Journal Of Nursing Practice}

http://thejnp.org

ISSN: 2614-3488 (print); 2614-3496 (online)

Vol.4 No.2. April 2021. Page.212-218

parts: body weight day 1 (BW1), body weight day 4 (BW4), body weight day 8 (BW8), and body weight day 12 (BW12). Instrument are Completed forms from medical records were used to obtain data from 2017 to 2018.

Data analysis

This investigation was conducted through secondary data resource (medical record). Homogenity among groups was examined using one-way Anova. Whereas the general linear model-repeated measure was used to quantify the contrast of increases in infants' body weight with normal data distribution among groups for days 4, 8, and 12 .

Ethical considerations

Since this was a retrospective study using medical records and no human contact, it did not need to comply with the Research Ethics Committee.

\section{RESULTS}

The characteristics of respondents in this study included gestational age, chronological age, birth weight, current weight, type of delivery, and sex.

Table 1

Respondents' demographic characteristics $(\mathrm{n}=75)$

\begin{tabular}{|c|c|c|c|c|c|c|c|c|c|c|c|}
\hline \multirow[b]{2}{*}{ Variabel } & \multicolumn{2}{|c|}{ BM 0\% } & \multicolumn{2}{|c|}{ BM 25\% } & \multicolumn{2}{|c|}{ BM 50\% } & \multicolumn{2}{|c|}{ BM 75\% } & \multicolumn{2}{|c|}{ BM 100\% } & \multirow{2}{*}{$\begin{array}{c}P \\
\text { value }\end{array}$} \\
\hline & $\begin{array}{l}\text { Mean } \\
\text { (n) }\end{array}$ & $\begin{array}{l}\text { SD } \\
(\%)\end{array}$ & $\begin{array}{c}\text { Mean } \\
\text { (n) }\end{array}$ & $\begin{array}{l}\text { SD } \\
(\%)\end{array}$ & $\begin{array}{c}\text { Mean } \\
\text { (n) }\end{array}$ & $\begin{array}{l}\text { SD } \\
(\%)\end{array}$ & $\begin{array}{c}\text { Mean } \\
\text { (n) }\end{array}$ & $\begin{array}{l}\text { SD } \\
(\%)\end{array}$ & $\begin{array}{l}\text { Mean } \\
\text { (n) }\end{array}$ & $\begin{array}{l}\text { SD } \\
(\%)\end{array}$ & \\
\hline $\begin{array}{l}\text { Gestational } \\
\text { age (wk) }\end{array}$ & 32,8 & 1,89 & 33,6 & 1,55 & 32,3 & 2,46 & 32,8 & 1,61 & 33,5 & 1,46 & 0,62 \\
\hline $\begin{array}{l}\text { Chronological } \\
\text { age (day) }\end{array}$ & 18,87 & 1,04 & 20,9 & 1,58 & 14,53 & 8,42 & 11,8 & 4,88 & 11,33 & 8,22 & 0,005 \\
\hline $\begin{array}{l}\text { Birth weight } \\
\text { (gr) }\end{array}$ & 1683 & 453,97 & 1742 & 356,20 & 1818 & 417,28 & 1731 & 392,94 & 1882 & 418,2 & 0,243 \\
\hline $\begin{array}{l}\text { Actual weight } \\
\text { (gr) }\end{array}$ & 2301 & 420,71 & 2288 & 383,49 & 2179 & 256,59 & 2079 & 281,39 & 2117 & 374,3 & 0,043 \\
\hline \multicolumn{12}{|c|}{ Type of delivery } \\
\hline $\mathrm{SC}$ & 11 & 73,3 & 11 & 73,3 & 9 & 60 & 10 & 66,7 & 11 & 73,3 & \multirow{2}{*}{0,862} \\
\hline Normal & 4 & 26,7 & 4 & 26,7 & 6 & 40 & 5 & 33,3 & 4 & 26,7 & \\
\hline \multicolumn{12}{|l|}{ Sex } \\
\hline Male & 10 & 66,7 & 5 & 33,3 & 7 & 45,7 & 6 & 40 & 8 & 53,3 & \multirow{2}{*}{0,629} \\
\hline Female & 5 & 33,3 & 10 & 66,7 & 8 & 53,3 & 9 & 60 & 7 & 46,7 & \\
\hline
\end{tabular}

= BM: Breast Milk

Table 2

General linear model with post-hoc analysis was used for predicting the association between the amount of breast milk consumption and preterm infants' body weight

\begin{tabular}{|c|c|c|c|c|c|c|}
\hline Increase in body weight & $\begin{array}{c}\text { BM 0\% } \\
(n=15) \\
\text { Mean } \\
\text { (SD) }\end{array}$ & $\begin{array}{c}\text { BM 25\% } \\
(n=15) \\
\text { Mean } \\
\text { (SD) }\end{array}$ & $\begin{array}{c}\text { BM 50\% } \\
(\mathrm{n}=15) \\
\text { Mean } \\
\text { (SD) }\end{array}$ & $\begin{array}{c}\text { BM 75\% } \\
(n=15) \\
\text { Mean } \\
\text { (SD) }\end{array}$ & $\begin{array}{c}\text { BM 100\% } \\
(n=15) \\
\text { Mean } \\
(\text { SD) }\end{array}$ & P value \\
\hline Increase: BW4-BW1 & $\begin{array}{c}77,4 \\
(71,284)\end{array}$ & $\begin{array}{c}47,80 \\
(91,806)\end{array}$ & $\begin{array}{c}108,80 \\
(248,135)\end{array}$ & $\begin{array}{c}13,47 \\
(104,695)\end{array}$ & $\begin{array}{c}56,27 \\
(108,493)\end{array}$ & 0,68 \\
\hline Increase: BW8-BW4 & $\begin{array}{c}115,67 \\
(83,364)\end{array}$ & $\begin{array}{c}66,80 \\
(102,364)\end{array}$ & $\begin{array}{c}46,67 \\
(202,764)\end{array}$ & $\begin{array}{c}144,33 \\
(99,071)\end{array}$ & $\begin{array}{c}136,80 \\
(129,267)\end{array}$ & 0,65 \\
\hline
\end{tabular}


Journal Of Nursing Practice

http://thejnp.org

ISSN: 2614-3488 (print); 2614-3496 (online)

Vol.4 No.2. April 2021. Page.212-218

\begin{tabular}{lcccccc}
\hline Increase: BW12-BW8 & $\begin{array}{c}163,33 \\
(76,827)\end{array}$ & $\begin{array}{c}109,40 \\
(73,473)\end{array}$ & $\begin{array}{c}128,60 \\
(134,187)\end{array}$ & $\begin{array}{c}78,20 \\
(132,770)\end{array}$ & $\begin{array}{c}43,33 \\
(145,353)\end{array}$ & 0,12 \\
\hline
\end{tabular}

\section{DISCUSSION}

Statistical analysis using the general linear model shows that there is no significant difference among the five nutritional intake types in regard to preterm infants' weight. The calorie content of breastfeeding is almost equal to formula feeding; thus, this indicates no difference regarding weight gain among preterm infants in the various nutritional intake groups. The calorie content of breast milk until two weeks chronological age is equal to formula milk for preterm infants (Padovani, Duarte, Martinez \& Linhares, 2011). In this study, the chronological age of preterm infants varied until 62 days. This condition could affect the calorie content of breast milk, and thus, it could have less calorie content than formula milk.

However, previous studies have shown the negative impact of formula on preterm infants (Shulhan, Dicken, Hartling \& Larsen, 2017). Kosmont (2011) stated that preterm infants who were formula fed have higher risk of NEC compared to preterm infants who were breastfed or received donated breast milk and breast milk with HMF. Breast milk has immunological, psychological, and economic benefits and enhances neurobehavioral and cognitive growth, gastrointestinal system maturity, and emotional bonding between mother and baby (Shulhan, Dicken, Hartling \& Larsen, 2011).

Breast milk for preterm infants contains more glycosaminoglycan, which aims to prevent enterocyte death. The bioactive molecule in breast milk could strengthen the baby's immune system and prevent NEC, which infant formula cannot do (Chowning, Radmacher, Lewis, Serke, Pettit \& Adamkin, 2015; Siggers, Thymann, Boye \& Sanglid, 2011). Colostrum given after birth contains growth factor and lactoferrin (Underwood, 2013). Dutta, Singh, Chessell, Wilson, Janes et al. (2015) stated that mother's own milk is the very first option for preterm infants. The second best alternative is donor milk, although some nutritional elements are inactivated by the pasteurization process (Bertino, Nicola, Giuliani, et al., 2012; Kumar, Singhal, Vaidya, Banerjee, Anwar et al, 2017; McGuire and Anthony, 2003). The last option is formula milk, for which the risks and benefits associated with NEC remain debatable (Walsh, Brown, Askie, Embleton, \& McGuire, 2019).

The normal increase of preterm infant weight is $15 \mathrm{grams} / \mathrm{kg} \mathrm{BW} /$ day after age 8-10 days. Bronchopulmonary dysplasia, patent ductus arteriosus, and respiratory distress could cause weight loss and increase morbidity and mortality in preterm infants (Caner, Tekgunduz, Temuroglu, Demirelli \& Kara, 2015). Weight gain could also be promoted by the Kangaroo Mother Care (KMC) method. KMC helps babies gain more weight, strengthens the emotional bond between mother and baby, controls body temperature, provides feelings of security and safety, has an analgesic effect, provides physiological function stability, calms the baby, boosts the blood flow to the brain, and shortens the hospitalization stay (Korraa, Nagger, Mohamed \& Helmy, 2014; Sarparast and Farhadi, 2015).

Too little or too much stimuli could affect the nervous synchronization system, and could damage their development and growth (Als and McAnulty, 2011). At the beginning of a preterm infant's life, there are several physiological functions that need stabilization and integration from medical equipment to help their survival, such as breathing, heart rate, temperature control, digestive function, and elimination. The best treatment to overcome environmental stress is developmental care (Hockenberry and Wilson, 2013). 


\section{Journal Of Nursing Practice}

http://thejnp.org

However, the implementation of developmental care in Indonesia is still not optimal. Constraints related to human resources, policies, and facilities are one of the obstacles to the perfect application of developmental care (Efendi and Rustina, 2013). Several developmental care standards that are generally implemented by hospitals include sound management in the treatment room, but developmental care such as sleep protection by providing nesting, minimal handling, reducing lighting, and kangaroo mother care have been implemented. Programs to improve bonding for mothers and babies have been carried out in several hospitals, for example through Mother Therapeutic Touch (MTT) for babies undergoing minor invasive procedures (Efendi et al., 2018), the use of breast feeding pillows for mothers with premature babies, and discharge planning programs. in the neonatology unit (Julianti, Rustina and Efendi, 2019).

\section{CONCLUSION}

This study concluded that there is no significant difference among the five nutritional intake types in terms of preterm infants' weight gain. Though the increase in preterm infants' weight were equal, consumption of mother's own milk is still more recommended over others due to its immunity components, nutritional elements, and safety. Nurses have a pivotal role as advocates for preterm infant formula use with rigorous considerations.

\section{Relevance to clinical practice}

This study provide evidence of the similarity of weight gain associated with the tipe of enteral nutrition in preterm infants in the first two weeks. Although breast milk does not accelerate the infants weight gain, aspect in safety, cost effectiveness, and imonological support make breastmilk remains superior to the other. The use of preterm formula should be accompanied by strong consideration. Nurses must provide support, as well as assistance to mothers who are experiencing problems in the production of breast milk. Collaboration with lactation councelor and peer support group might be needed to improve lactation coverage of the preterm infant in special care nursery.

\section{ACKNOWLEDGMENTS}

The authors are indebted to all of the neonatal nurses in Cipto Mangunkusumo national top referral hospital Jakarta, Indonesia.

\section{CONFLICTS OF INTEREST}

We declare there is no conflict of interest in this study 


\section{Journal Of Nursing Practice}

http://thejnp.org

ISSN: 2614-3488 (print); 2614-3496 (online)

Vol.4 No.2. April 2021. Page.212-218

\section{REFERENCES}

Ahammad, F., Begum, T. and Nasrin, E. (2018). Comparison of feeding intolerance between very preterm and moderate preterm neonates - a prospective cohort study. Journal of Pediatrics and Neonatal Care, 8(4), pp. 6-10. doi: 10.15406/jpnc.2018.08.00339.

Als, H. and McAnulty, G. B. (2011). The Newborn Individualized Developmental Care and Assessment Program (NIDCAP) with Kangaroo Mother Care (KMC): Comprehensive Care for Preterm Infants. Curr Womens Health Rev, 7(3), pp. 288301. https://doi.org/10.2174/157340411796355216.

Bertino, E. et al. (2012). Benefits of human milk in preterm infant feeding. Journal of Pediatric and Neonatal Individualized Medicine, 1(1), pp. 19-24. https://doi.org/10.7363/010102.

Caner, I., Tekgunduz, K. S., Temuroglu, A., Demirelli, Y., \& Kara, M. (2015) Evaluation of Premature Infants Hospitalized in Neonatal Intensive Care Unit between 20102012. Eurasian J Med, pp. 13-20. https://doi.org/10.5152/eajm.2014.38.

Chowning, R. et al. (2015). A retrospective analysis of the effect of human milk on prevention of necrotizing enterocolitis and postnatal growth. Journal of Perinatology. Nature Publishing Group, 36(3), pp. 221-224. https://doi.org/10.1038/jp.2015.179.

Dutta, S. et al. (2015). Guidelines for Feeding Very Low Birth Weight Infants. Nutrients, 7, pp. 423-442. https://doi.org/10.3390/nu7010423.

Efendi, D. et al. (2018). Combination of Mother Therapeutic Touch (MTT) and Maternal Voice Stimulus (MVS) therapies stabilize sleep and physiological function in preterm infants receiving minor invasive procedures. Journal of Neonatal Nursing, (March), pp. 1-7. https://doi.org/10.1016/j.jnn.2018.08.001.

Efendi, D. and Rustina, Y. (2013). Newborn Individualized Developmental Care And Assessment Program (NIDCAP) Terhadap Hasil Jangka Panjang Perkembangan Bayi Prematur: Suatu Telaah. Jurnal keperawatan indonesia, 16(3), pp. 161-167. doi: https://doi.org/10.7454/jki.v16i3.326.

Hockenberry, M. J. and Wilson, D. (2013). Wong's Essentials of Pediatric Nursing. 9th edn. St. Louis Missouri: Elsevier Mosby.

Julianti, E., Rustina, Y. and Efendi, D. (2019). Discharge Planning Could Increase Mother's Knowledges and Skills With Preterm Baby (Program Perencanaan Pulang Dapat Meningkatkan Pengetahuan Dan Keterampilan Ibu Yang Melahirkan Bayi Prematur Merawat Bayinya). Jurnal Keperawatan Indonesia, 22(1), pp. 74-81. https://doi.org/10.7454/jki.v22i1.540.

Korraa, A. A. et al. (2014). Impact of kangaroo mother care on cerebral blood flow of preterm infants. Korraa et al. Italian Journal of Pediatrics, 40(83), pp. 1-6. https://doi.org/10.1186/s13052-014-0083-5.

Kosmont, L. (2011). Prolacta bioscience applauds Johns Hopkins research reinforcing benefits of human milk over formula for extremely premature. J Pediatr, 4(156), pp. 562-567. https://doi.org/10.1016/j.jpeds.2009.10.040

Kumar, R. K. et al. (2017). Optimizing nutrition in preterm low birth weight infants Consensus summary. Frontiers in Nutrition, 4(May), pp. 1-9. https://doi.org/10.3389/fnut.2017.00020.

McGuire, W. and Anthony, M. Y. (2003). Donor human milk versus formula for preventing necrotising enterocolitis in preterm infants: systematic review. Arch Dis Child Fetal Neonatal, 88, pp. 11-14. http://dx.doi.org/10.1136/fn.88.1.F2-a 


\section{Journal Of Nursing Practice}

http://thejnp.org

Meier, P. P. et al. (2010). Improving the Use of Human Milk During and After the NICU Stay. Clin Perinatol., 37(1), pp. 217-245. https://doi.org/10.1016/j.clp.2010.01.013.Improving.

Namiiro, F. B. et al. (2012). Poor birth weight recovery among low birth weight / preterm infants following hospital discharge in Kampala. Uganda', pp. 1-7. https://doi.org/10.1186/1471-2393-12-1

Padovani, F. H. P., Duarte, G., Martinez, F. E., \& Linhares, M. B. M. (2011). Perceptions of breastfeeding in mothers of babies born preterm in comparison to mothers of fullterm babies. The Spanish Journal of Psychology, 14(2), 884-898. http://dx.doi.org/10.5209/rev_SJOP.2011.v14.n2.35

Sarparast, L. and Farhadi, R. (2015). The Effect of Kangaroo Mother Care on Neonatal Outcomes in Iranian Hospitals : A Review The Effect of Kangaroo Mother Care on Neonatal Outcomes in Iranian Hospitals: A Review. J Pediatr Rev, 3(1). https://doi.org/10.5812/jpr.195.

Shulhan, J. et al. (2017). Current Knowledge of Necrotizing Enterocolitis in Preterm Infants and the Impact of Different Types of Enteral Nutrition Products. Advance in Nutrition, (9), pp. 80-91. https://doi.org/10.3945/an.116.013193.80.

Siggers, R. H. et al. (2011). Nutritional modulation of the gut microbiota and immune system in preterm neonates susceptible to necrotizing enterocolitis. The Journal of Nutritional Biochemistry. Elsevier Inc., 22(6), pp. 511-521. https://doi.org/10.1016/j.jnutbio.2010.08.002.

Underwood, M. A. (2013). Human milk for the premature infant. Pediatr Clin North Am, 60(1), pp. 189-207. https://doi.org/10.1016/j.pcl.2012.09.008.Human.

Walsh, V., Brown, J.V.E., Askie, L.M., Embleton, N.D., \& McGuire, W. (2019). Nutrientenriched formula versus standard formula for preterm infants. Cochrane Database of Systematic Reviews, 7. https://doi.org/10.1002/14651858.CD004204.pub3.

Wojkowska-Mach, J., Rozanska, A., Borszewska-Kornacka, M., Domanska, J., Gadzinowski, J., Gulczynska, E., Helwich, E., Kordek, A., Pawlik, D., Szczapa, J., \& Heczko, P. B. (2014). Necrotising Enterocolitis in Preterm Infants : Epidemiology and Antibiotic Consumption in the Polish Neonatology Network Neonatal Intensive Care Units in. Plosone, 9(3). https://doi.org/10.1371/journal.pone.0092865. 